\title{
THE EFFICACY AND SAFETY OF CORTICOSTEROIDS IN THE TREATMENT OF ACUTE AND CHRONIC PAIN
}

\author{
Nebojsa Nick Knezevic ${ }^{1,2,3}$, Dimitry Voronov ${ }^{1}$, Kenneth D. Candido ${ }^{1,2}$ \\ ${ }^{1}$ Department of Anesthesiology, Advocate Illinois Masonic Medical Center, Chicago, IL \\ ${ }^{2}$ Department of Anesthesiology, University of Illinois, Chicago, IL \\ ${ }^{3}$ Department of Surgery, University of Illinois, Chicago, IL
}

\section{Abstract}

Over the past three decades, corticosteroids have become part of a multimodal approach in the management of both cervical and lumbar degenerative disc diseases. Pain management specialists from various fields had a front row seat, and actively participated in the evolution from primarily oral steroid therapy to the development of various fluoroscopically-guided epidural steroid injection approaches. In this review we discuss the different forms of oral and injectable corticosteroids that have been used by different physician specialties in treating acute and chronic pain. We delineate differences between longer-acting particulate ('insoluble') (i.e. methylprednisolone and triamcinolone) and shorter-acting non-particulate steroids ('soluble') (i.e. betamethasone and dexamethasone), and their utilization while performing different epidural injections. We also discuss the presence of different preservatives in the injectable corticosteroid preparations, as well as some simple techniques to reduce the preservative concentrations, which might improve the safety of those injections. Furthermore, we want to illustrate the existing debates within the pain management physician community with regards to the current guidelines as they pertain to the type of steroids, techniques and approaches used to manage radicular type spinal pain. We discuss the underutilization and overutilization of selected injection techniques and some concerns that the United States Food and Drug Administration (FDA) raised, regarding the safe use of corticosteroids in pain management. We also elaborate upon the usefulness of some expensive tools such as digital subtraction angiography, which has been promoted by some in the medical community, and the difference in surgery rates for patients that have been treated by different physician specialties who use corticosteroids to manage pain. This review will emphasize that there is always room for improvement with respect to the following of published guidelines, and will accentuate the importance of reviewing the literature prior to making important clinical decisions.

Key words: efficacy; safety; corticosteroids; acute pain; chronic pain

\section{Sažetak}

U protekle tri decenije kortikosteroidi su postali deo multimodalnog pristupa u terapiji degenerativnih oboljenja kako cervikalnog, tako i lumbalnog dela kičmenog stuba. Specijalisti terapije bola su aktivno učestvovali u evoluciji pristupa terapiji koja ide od oralnih kortikosteroda do različitih epiduralnih injekcija rukovodjenim fluoroskopskim tehnikama. U okviru ovog rada mi diskutujemo različite forme oralnih $i$ injektibilno primenjenih kortikosteroida koje koriste različiti specijalisti prilikom lečenja akutnog $i$ hroničnog bola. Ovde razmatramo razlike izmedju čestičnih preparata sa produženim dejstvom, kao što su metilprednizolon ili triamcinolone, kao $i$ onih ne-čestičnih sa kratkim dejstvom kao što su betametazon ili deksametazon i njihovog korišćenja u vidu epiduralnih injekcija. Diskutujemo i o prisustvu različitih prezervativnih materija u kortikosteroidnim preparatima injekcija, kao i jednostavnim tehnikama za smanjenje koncentracije prezervativnih materija koje bi mogle poboljšati bezbednost ovih injekcija. Nadalje, želimo da prikažemo postojeću raspravu među specijalistima koji se bave terapijom bola, a koja se odnosi na trenutne protokole o upotrebi različitih vrsta kortikosteroida, tehnika i pristupa koji su korišćeni. Diskutujemo takođe i preterano korišćenje ili nedovoljnu upotrebu pojedinih injekcionih tehnika i neke dileme prepoznate od strane Američke Agencije za Lekove (FDA) koje se tiču bezbednosti upotrebe kortikosteroida u terapiji bola. Takode razmatramo i korist nekih skupliih tehnika kao sto je digitalna subtrakciona angiografija, koja se trenutno promoviše u medicinskoj zajednici, kao i razlike u učestalosti podvrgavanja pacijenata invazivnim operativnim tehnikama u tretmanu bola, a koji dolaze od doktora različitih specijalnosti. Ovaj rad pokazuje da uvek postoji prostor za unapređenje postojećih protokola $i$ naglašava važnost upoznavanja sa medicinskom literaturom $i$ iskustvima specijalista u terapiji bola prilikom donošenja budućih terapijskih odluka.

Ključne reči: efikasnost; bezbednost; kortikosteroidi; akutni bol; hronični bol 


\section{The Efficacy and Safety of Corticosteroids in the Treatment of Acute and Chronic Pain}

$\mathrm{O}^{2}$ ver the past three decades, corticosteroids of the glucocorticoid type administered by oral, intramuscular, intravenous, transcutaneous and neuraxial injection routes have become part of a multimodal approach in the management of both cervical and lumbar degenerative disc disease. Pain management specialists from various fields had a front row seat, and actively participated in the evolution from oral steroid therapy to the development of various fluoroscopy-guided intrathecal and epidural steroid injection approaches. These innovative advances sparked research aimed to determine exactly which method was superior at alleviating radicular back and neck pain. The purpose of this review is both to provide a background regarding the evolution of steroid use in pain management as well as to illustrate the current debates that exist within the pain management community in regards to the type of steroids, techniques and approaches used to manage chronic radicular type spinal pain. This review will emphasize that there is always room for improvement with respect to the current published guidelines, and accentuate the importance of reviewing the literature prior to making important clinical decisions.

\section{Mechanism of Clinical Efficacy of Glucocorti- costeroids}

The mechanism of action of corticosteroids can largely be explained by cytokine suppression. In 2014, Risbud and Shapiro discussed the role of cytokines in the development of intervertebral disc generation. ${ }^{1}$ Their highlighted pathway begins with an insult (i.e. trauma, infection), followed by the release of cytokines including tumor necrosis factor alpha (TNF), interleukin 1-beta (IL-1 $\beta$ ) and interleukin-6 (IL-6). These cytokines promote immunocyte activation and migration, which initiates a molecular cascade, resulting in intervertebral disc degeneration and eventual radicular back and/or neck pain. The role of corticosteroids, through the inhibition of phospholipase A2 (PLA-2) and the subsequent arachidonic acid pathway, is to both directly and indirectly minimize the synthesis/ release of these cytokines. Consequently, this proposed cytokine suppression results in mitigation of disc degeneration and pain expression.

\section{Different Injectable Steroids}

In 2005, Webster et al. surveyed 720 physicians manage acute low back pain, including family medicine physicians, general practitioners, internal medicine, osteopathic medicine and emergency medicine specialists to compare the approach to the initial management of acute back pain. ${ }^{2}$ The study showed that nearly $25 \%$ of the physicians prescribed systemic corticosteroids as the initial management for patients with low back pain-related sciatica. The use of oral steroids in the treatment of sciatica, however, has historically proven to be without merit. In 1986, Haimovic and Beresford studied the efficacy of oral dexamethasone in 33 patients with lumbosacral radicular pain. They used a 7-day taper oral dose: $64 \mathrm{mg}, 32 \mathrm{mg}, 16 \mathrm{mg}$, $12 \mathrm{mg}$ and $8 \mathrm{mg}$ (2 days) and showed insignificantly different short- and long-term relief of sciatica pain when compared to placebo. ${ }^{3}$ In 2008 , Holve and Barkan found similar results with oral prednisone. ${ }^{4}$ They compared a 9-day tapering dose of prednisone (60 mg, $40 \mathrm{mg}$ and $20 \mathrm{mg}$ ) to a placebo group. They followed-up patients weekly in the first month, and then monthly for 5 months, and compared leg and back pain scores, use of analgesics, and quality of life and functionality questionnaires and showed that early use of oral prednisone had no significant improvement in sciatica patients. ${ }^{4}$ In recent years, due to the lack of efficacy of oral corticosteroids in alleviating low back pain, attention and research has turned to an examination of the use of epidural steroid injections. This transition is supported by data showing improvement in symptoms, better treatment satisfaction scores and cost-effectiveness when steroid injections are used alone, or in addition with other modalities for managing low back pain. ${ }^{5-6}$ Huiges et al. compared 33 patients who underwent steroid injections added for the treatment of the lumbar radicular syndrome compared to 30 control patients and showed better treatment satisfaction scores ( 9 vs. 72$)(\mathrm{p}=0.006){ }^{5}$ In another study by the same authors they compared two groups of 25 patients each and showed better improvement in physical domain on SF-36 questionnaires in those undergoing the spinal intervention than in the control group. ${ }^{6}$

The different injectable steroids can be divided into two groups: particulate ('insoluble') and non-particulate ('soluble'). Particulate steroids (i.e. methylprednisolone and triamcinolone) are 
longer-acting, thus requiring fewer repeated injections; however, particulate steroids possess the potential to cause spinal cord and brain infraction secondary particulate embolization if injected arterially. Non-particulates (i.e. betamethasone and dexamethasone) are shorter-acting, and thus less cost-effective. Tiso et al. ${ }^{7}$ looked at different corticosteroids under electron microscopy and measured the size of particles. They showed that $8.6 \%$ of methylprednisolone and $3.7 \%$ of triamcinolone particles are larger than 100 microns.

Kennedy et al. conducted a randomized, double-blind study comparing the effect of non-particulate (dexamethasone) and particulate steroids (triamcinolone) when used in transforaminal epidural steroid injections (TFESI). ${ }^{8}$ They showed that the incidence of patients requiring a third TFESI to control radicular pain was six-times greater among 41 patients receiving dexamethasone $(17.1 \%)$ compared to 37 patients that received triamcinolone ( $2.7 \%) .{ }^{8}$ On the positive side is that non-particulates, while being less effective clinically, do not possess the same potential for infarction as do the particulate steroids.

\section{Preservatives in Corticosteroid Injections}

Steroids not only differ in their chemical structures or particle size, but also in the types of preservatives used during manufacturing. In 2012, the Centers for Disease Control and Prevention (CDC) and Food and Drug Administration (FDA) investigated a multi-state outbreak of fungal meningitis, presumably caused by epidural injection of contaminated preservative-free steroids. ${ }^{9}$ While this appeared to have been a result of faulty manufacturing at one location (New England Compounding Center-NECC; Framingham, MA), it did highlight some of the challenges related to the preparation of glucocorticoids when attempts are made to make them "preservative-free". As a result, most of the commonly used steroid preparations contain preservatives (i.e. polyethylene glycol, benzyl alcohol, myristyl-gamma-picolinium chloride) in order to maintain sterility and also increase shelf life. While the fungal meningitis example showed the relative lack of risks of using commercially-prepared steroids with added preservatives, negative effects from those same preservatives have also been documented. In 2011, Candido et al. proved that by inverting a vial of commercially-prepared methylprednisolone and waiting for the polyethylene glycol to separate from the steroid, one could significantly reduce the concentration of polyethylene glycol in a given injection. ${ }^{10}$ The significance of this was reiterated in 2014, when Knezevic et al. showed that a decreased concentrations of polyethylene glycol resulted in a significantly smaller percentage of apoptotic dorsal root ganglion sensory cells in rats. ${ }^{11}$ This study highlighted the potentially dangerous side-effects of added preservatives.

\section{Which Approach is Best for Using Epidural Steroids? Caudal; Transforaminal; Interlaminar}

Interlaminar epidural steroid injections (ILESIs), transforaminal epidural steroid injections (TFESIs) and caudal injections are the most commonly used and studied approaches for epidural injections. Although there is conflicting data about which technique is superior, one steadfast fact holds true. Three systematic reviews from 2012 showed that for chronic radiculitis secondary to intervertebral disc herniation, the addition of corticosteroids to local anesthetics used alone for injection can increase the efficacy of all three approaches. ${ }^{12-14}$ Parr et al. included 16 studies that used the caudal approach (11 of them were randomized) and showed good evidence for shortand long-term pain relief secondary to herniated discs and radicular pain when both corticosteroids and local anesthetics are used together. ${ }^{12}$ They also showed fair pain relief in patients with axial or discogenic pain, spinal stenosis or failed back surgery syndrome (FBSS) when only local anesthetics were used. ${ }^{12}$ Benyamin et al. reviewed 26 studies that used lumbar interlaminar approach for lumbar epidural steroid injections (ILESI), and 15 of them were randomized. ${ }^{13}$ They showed good evidence of efficacy of corticosteroids with local anesthetics in the treatment of radicular pain secondary to disc herniation, and fair evidence when only local anesthetics were used for the treatment of spinal stenosis and axial pain. ${ }^{13}$ Manchikanti et al. reviewed 27 studies (15 randomized) that used a transforaminal approach (TFESI) for managing lumbar radicular pain. ${ }^{14}$ They showed good effectiveness of these injections in patients with radicular pain secondary to disc herniation when steroids and local anesthetics were used, and fair evidence when only local anesthetics were used. However, the injections had a very limited effect in patients with 
axial pain or failed back surgery syndrome (FBSS) regardless of whether steroids were added to the local anesthetics or not. ${ }^{14}$

As previously mentioned, conflicting data exists with regards to ILESI versus TFESI in the treatment of sciatica. In their review article from 2013, Cohen et al. concluded that TFESIs are more effective than other routes of administration in managing back pain. ${ }^{15}$ However, Chang Chien et al. challenged this conclusion in another systematic review and meta-analysis. ${ }^{16}$ They included only studies that directly compared these two approaches (ILESI vs. TFESI), and those studies when injections were performed under fluoroscopic guidance. A total of 506 patients with no prior back surgeries were included, and results showed that both TFESI and ILESI are effective in reducing pain and improving functional scores in patients with unilateral lumbosacral radicular pain. TFESI showed non-clinically significant superiority to ILESI only at the 2-week follow-up. However, based on two studies, ILESI demonstrated non-clinically significant superiority to TFESI in functional improvement. ${ }^{16}$

\section{Surgery Rates Affected by Different Injectable Techniques}

The natural question is whether or not epidural steroid injections in general can prevent the requirement for spinal surgery. Originally, lumbar TFESI had a seeming advantage when it came to requirements for spinal surgery. Comparing studies to find an answer to this question is difficult due to the differences in a) approach (TFESI vs. ILESI), b) steroid used (particulate vs. non-particulate) and c) patient population (acute vs. chronic disease). Riew et al. showed that $29 \%$ of patient that received betamethasone required surgery during a 13-to-28-month follow-up. ${ }^{17}$ Kennedy et al. looked at 78 randomized patient receiving TFESI with either dexamethasone or triamcinolone. ${ }^{8}$ This study produced a relatively high surgery rate at three months (14.6\% for dexamethasone and $16.2 \%$ for triamcinolone). ${ }^{8}$ Knezevic et al. challenged this high surgery rate and commented on the differences in surgery rates when patients are seen by different specialists who are treating back pain (interventional pain physicians vs. orthopedic surgeons). ${ }^{18}$ Candido et al. conducted a prospective, randomized, double-blind study comparing two different needle approaches for ILESI injections (midline vs. parasagittal) in 106 patients that were followed up for one year. ${ }^{19}$ They showed that the parasagittal ILESI approach was more effective in targeting unilateral radicular low back pain secondary to degenerative lumbar disc disease. They also showed that pressure paresthesias occurring ipsilaterally (on the same side as the usual and customary radicular type pain) during injection correlated with pain relief and may therefore be used as a prognostic factor. They also showed that only $4 \%$ of those patients ended up having a spine surgery during the one-year follow-up, ${ }^{19}$ which is much lower percentage than that in the Kennedy et al. study when TFESI approach was used. ${ }^{8}$ These studies illustrate the hurdles in making a consensus statement with regards to surgery rates.

\section{FDA Warning from April 23, 2014}

On April 23, 2014 the FDA issued a warning that injection of corticosteroids into the epidural space may result in rare but serious adverse events, including loss of vision, stroke, paralysis and death. ${ }^{20}$ This warning drew immediate scrutiny from the pain management community for two main reasons. First, the references in this letter were heavily skewed towards the transforaminal approach (higher incidence of vascular compromise), and none of the references mentioned concern with lumbar interlaminar epidural steroid injections. Additionally, 12 out of 15 cases depicting the above adverse events occurred following injection of particulate steroids. ${ }^{21}$ While taking the FDA warning seriously, it was important to point out that not all epidural steroid injections were created equal, and thus not all injections carried the same generalized risk depicted by the FDA.

\section{Multidisciplinary Working Group (MWG) Recommendations}

In 2015, in response to the FDA safety concerns, Rathmell et al. published a list of guidelines based on consensus opinions from 13 different societies. ${ }^{22}$ Due to their presented increased overall risk of complications, these guidelines primarily focus on safety as it pertains to cervical ESIs and TFESIs of both cervical as well as lumbar spines. In addition, the recommendations highlighted the importance of using sterile technique, fluoroscopy-guidance (when no contraindications exist), and the usage of 
Table 1.

\begin{tabular}{|c|c|c|c|c|c|}
\hline Author & $\begin{array}{l}\text { Journal and year } \\
\text { of publication }\end{array}$ & $\begin{array}{l}\text { Type } \\
\text { of Study }\end{array}$ & $\begin{array}{l}\text { Total } \\
\text { Number } \\
\text { of Patient }\end{array}$ & Study Groups & Key Finding(s) \\
\hline Haimovic et al.[3] & Neurology 1986 & $\begin{array}{l}\text { Prospective, } \\
\text { double-blind }\end{array}$ & 33 & $\begin{array}{l}\text { Dexamethasone } \\
\text { vs. placebo }\end{array}$ & $\begin{array}{l}\text { Dexamethasone is not } \\
\text { superior to placebo for } \\
\text { treating sciatica }\end{array}$ \\
\hline Holve et al.[4] & JABFM 2008 & $\begin{array}{l}\text { Double-blind, } \\
\text { controlled }\end{array}$ & 27 & $\begin{array}{l}\text { Prednisone vs. } \\
\text { placebo }\end{array}$ & $\begin{array}{l}\text { Oral steroid medication } \\
\text { in patients with sciatica } \\
\text { had no significant effect } \\
\text { on most parameters } \\
\text { studied }\end{array}$ \\
\hline Huiges et al.[5] & $\begin{array}{l}\text { BMC } \\
\text { Musculoskeletal } \\
\text { Disorders } 2014\end{array}$ & $\begin{array}{l}\text { Pragmatic, } \\
\text { single- } \\
\text { blinded, } \\
\text { randomized } \\
\text { controlled } \\
\text { trial }\end{array}$ & 63 & $\begin{array}{l}\text { Care as usual vs. } \\
\text { epidural steroid } \\
\text { injection }\end{array}$ & $\begin{array}{l}\text { Patients from the } \\
\text { intervention group } \\
\text { were significantly } \\
\text { more satisfied with the } \\
\text { received treatment. } \\
\text { Positive effect of } \\
\text { SESIs on back pain, } \\
\text { impairment and } \\
\text { disability in acute LRS }\end{array}$ \\
\hline Huiges et al.[6] & $\begin{array}{l}\text { Archives of } \\
\text { Physical Medicine } \\
\text { and Rehabilitation } \\
2015\end{array}$ & $\begin{array}{l}\text { pragmatic } \\
\text { randomized } \\
\text { controlled } \\
\text { trial }\end{array}$ & 50 & $\begin{array}{l}\text { Care as usual vs. } \\
\text { epidural steroid } \\
\text { injection }\end{array}$ & $\begin{array}{l}\text { Both groups show } \\
\text { improvement in } \\
\text { physical domains } \\
\text { (SF-36): Intervention } \\
\text { group scored better } \\
\text { than control group. } \\
\text { Cost-effectiveness } \\
\text { acceptability curve } \\
\text { implies that utility of } \\
\text { adding ESI to usual } \\
\text { care is cost-effective at } \\
80 \% \text { without additional } \\
\text { investment }\end{array}$ \\
\hline Candido et al.[19] & $\begin{array}{l}\text { Pain Physician } \\
2013\end{array}$ & $\begin{array}{l}\text { Prospective, } \\
\text { randomized, } \\
\text { blinded study. }\end{array}$ & 106 & $\begin{array}{l}\text { ILESI midline vs. } \\
\text { PSILESI }\end{array}$ & $\begin{array}{l}\text { PSILESI was more } \\
\text { effective in targeting low } \\
\text { back pain with unilateral } \\
\text { radicular pain secondary } \\
\text { to degenerative lumbar } \\
\text { disc disease. Pressure } \\
\text { paresthesia occurring } \\
\text { ipsilaterally correlates } \\
\text { with pain relief and may } \\
\text { therefore be used as a } \\
\text { prognostic factor }\end{array}$ \\
\hline Kennedy et al.[8] & $\begin{array}{l}\text { Pain Medicine } \\
2014\end{array}$ & $\begin{array}{l}\text { prospective, } \\
\text { randomized, } \\
\text { double-blind } \\
\text { trial }\end{array}$ & 78 & $\begin{array}{l}\text { Dexamethasone } \\
\text { vs. triamcinolone }\end{array}$ & $\begin{array}{l}\text { Dexamethasone appears } \\
\text { to possess reasonably } \\
\text { similar effectiveness } \\
\text { when compared with } \\
\text { triamcinolone. However, } \\
\text { the dexamethasone } \\
\text { group received slightly } \\
\text { more injections than } \\
\text { the triamcinolone group } \\
\text { to achieve the same } \\
\text { outcomes. }\end{array}$ \\
\hline
\end{tabular}


non-particulate steroids during situations when the chance of vascular/intrathecal injection is higher. Overall, the recommendations served as an answer to the seemingly misrepresented FDA warning; however close scrutiny of those recommendations reveaed that they were deeply flawed. Mainly, the recommendations tended to promote the more costly use of non-particulate steroids and digital subtraction angiography (DSA) as a fluoroscopy technique, which allegedly increases the likelihood of visualizing blood vessels in contrast to dense tissues (i.e. bone or cartilage). This technique was mentioned in the MWG report as a valid alternative to use of real-time fluoroscopy when performing lumbar TFESIs. However, there is at best, minimal evidence in favor of its use and several compelling studies and case reports documenting the failure of DSA. DSA fails to discriminate between arterial and venous injection, and exposes patients to greater levels of radiation than standard fluoroscopy use. ${ }^{23}$ Additionally, Chang Chien et al. published a case report showing that DSA does not reliably prevent paraplegia associated with lumbar TFESI. ${ }^{24}$

\section{Conclusion}

It is evident that the field of pain management has come a long way in the last 20 years. Without question, epidural steroid injections are a significant part of the multimodal approach of managing radicular back and neck pain. However, it is important to pay close attention to the risks/benefits of their use, which pertains to patient safety and cost-effectiveness. This review emphasizes that the current guidelines of the MPW and other societies are not perfect, and the decisions of each pain management provider requires not to blindly follow the guidelines, but tailor the interventional pain treatment strategy to each individual patient instead.

\section{References}

1. Risbud MV, Shapiro IM. Role of cytokines in intervertebral disc degeneration: pain and disc-content. Nat Rev Rheumatol. 2014; 10(1) 44-56. doi: 10.1038

2. Webster BS, Courtney TK, Huang YH. BRIEF REPORT: Physicians' initial management of acute low back pain versus evidence-based guidelines. J Gen Intern Med.2005; 20 : 1132-1135.

3. Haimovic IC, Baresford HR. Dexamethosone is not superior to placebo for treating lumbosacral radicular pain. Neurology 1986; 36: 1593-1594.
4. Holve RL, Barkan H. Oral steroids in initial treatment of acute sciatica. JABFM 2008: 21(5).

5. Huiges AS, Winters JC, vanWijhe M, Groenier K. Steroid injections added to the usial treatment of lumbar radicular syndrome: a pragmatic randomized controlled trial in general practice. BMC Musculoskeletal Disorders 2014; 15:341.

6. Huiges AS, Vermeulen K, Winters JC et al. Epidural steroids for lumbosacral radicular syndrome compared to usual care: quality of life and cost utility in general practice. Archives of Physical Medicine and Rehabilitation 2015; 96:381-7.

7. Tiso RL, Cutler T, Catania JA, Whalen K. Adverse central nervous system sequelae after selective transforaminal block: the role of corticosteroids. The Spine Journal 2004;4:468-74.

8. Kennedy DJ, Pastaras C, Casey E et al. Comparative effectiveness of lumbar transforaminal epidural steroid injections with particulate versus non-particulate corticosteroids for lumbar radicular pain due to intervertebral disc herniation: a prospective, randomized, double-blind trial. Pain $\mathrm{Me}$ dicine 2014; 15: 543-555.

9. Pettit AC, Kropski JA, Castilho JL. The index case for the fungal meningitis outbreak in the United States. NEJM 2012.

10. Candido KD, Knezevic I, Mukalel J, Knezevic NN. Enhancing the relative safety of intentional or unintentional intrathecal methylprednisolone administration by removing polyethylene glycol. Anesthesia \& Analgesia 2011; 113(6).

11. Knezevic NN, Candido KD, Cokic I et al. Cytotoxic effect of commercially available methylprednisolone acetate with and without reduced preservatives on dorsal root ganglion sensory neurons in rats. Pain Physician 2014; 17: E609-E618.

12. Parr AT, Manchikanti L, Hameed H et al. Caudal epidural injections in the management of chronic low back pain: a systematic appraisal of the literature. Pain Physician 2012; 15:E159-E198.

13. Benyamin RM, Manchikanti L, Parr AT et al. The effectiveness of lumbar interlaminar epidural injections in managing chronic low back and lower extremity pain. Pain Physician 2012; 15:E363-E404.

14. Manchikanti L, Buenaventura RM, Manchikanti KN et al. Effectiveness of therapeutic lumbar transforaminal epidural steroid injections in managing lumbar spinal pain. Pain Physician 2012;15:E199-E245

15. Cohen SP, Bicket MC, Jamison D et al. Epidural steroids: A comprehensive, evidence-based review. Reginal Anesthesia and Pain Medicine 2013; 38(3).

16. Chang Chien GC, Knezevic NN, McCormick Z et al. Transforaminal versus interlaminar approach to epidural steroid injections: a systematic review of comparative studies for lumbosacral radicular pain. Pain Physician 2014; 17:E509-E524.

17. Riew KD, Yin Y, Gilula, L et al. The effect of nerve-root injections on the need for operative treatment of lumbar radicular pain. A prospective, randomized, controlled, double-blind study. J Bone Joint Surg Am 2000; 82: 1589-93.

18. Knezevic NN, Lissounov A, Candido KD. Transforaminal vs interlaminar epidural steroid injections: differences 
in the surgical rates and safety concerns. Pain Medicine2014; 15: 1975-1988.

19. Candido KD, Rana MV, Sauer R, Chupatanakul L, Tharian A, Vasic V, Knezevic NN. Concordant pressure paresthesia during interlaminar lumbar epidural steroid injections correlates with pain relief in patients with unilateral radicular pain. Pain Physician. 2013; 16(5):497-511.

20. U.S. Food and Drug Administration: Drug Safety Communications. FDA requires label changes to warn of rare but serious neurologic problems after epidural corticosteroid injections for pain. April 23, 2014. Available at: www. fda.gov/downloads/Drugs/Drug-Safety/UCM394286.pdf. Accessed August 16. 2016.

21. Candido KD, Knezevic NN, Chang Chien GC, Deer TR. The food and drug administration's recent action on April
23, 2014 failed to appropriately address safety concerns about epidural steroid use. Pain Physician 2014; 17:E549-E557.

22. Rathmell JP, Benzon HT, Dreyfuss P et al. Safeguards to prevent neurologic complications after epidural steroid injections: consensus opinions from a multidisciplinary working group and national organizations. Anesthesiology 2015; 122:974-84.

23. Candido KD. Critical items to consider before adopting advocacy of digital subtraction angiography. Pain Physician 2015; 18:37-38.

24. Chang Chien GC, Candido KD, Knezevic NN. Digital subtraction angiography does not reliably prevent paraplegia associated with lumbar transforaminal epidural steroid injection. Pain Physician 2012; 15: 515-523. 